\title{
The Effect of Teaching and Learning of Castles and Rounders on the Improvement of Physical Fitness
}

\author{
Sucipto, Herita Warni, Syamsul Arifin \\ Department of Sport and Health Education \\ Lambung Mangkurat University \\ Banjarmasin, Indonesia \\ sucipto70@yahoo.com
}

\begin{abstract}
This research aims to determine the effect of teaching and learning of Castles and Rounders Game on Improvement of Physical Freshness. This research used is the Pre-Experimental design method. The research was conducted based on One-Group Pretest-Posttest Design, involving 47 students of the fifth-grade with the ages of 10- 12 years old, from the State Elementary School of Pelaihari (SDN Pabahanan), Tanah Laut Regency. The sample was selected using a purposive sampling technique. The results of this research showed that $t$-count $\mathbf{- 1 7 . 9 4 7}$ is smaller than t-table, 1.68. This indicates that there is a significant difference between the average values for the pre-test data $=\mathbf{2 . 9 6}$ and the average value for the post-test data $=4.17$. These results indicate that the physical fitness level of the fifth-grade students of SD Negeri Pabahanan after getting the teaching and learning with the ball game of Castles and rounders increased by 1.21 or by $40.87 \%$. The results of this research conclude that there is a significant influence of the teaching and learning about Castles and Rounders on the physical fitness of the fifth-grade students of SD Negeri Pabahanan, Tanah Laut Regency.
\end{abstract}

Keywords: effects of learning, ball Games of castles, rounders, physical fitness

\section{INTRODUCTION}

Humans move for life. Motion is a characteristic of life. Humans move with various motions to do physical activities or sports to improve and maintain the quality of life. In carrying out the functions of life, humans will not be separated from education. This is because education serves to improve the quality of human resources. Through education, humans can read, write, talk, get a job, or get income to meet their daily needs. The educational process can be anywhere and last a lifetime, both in the family, playing environment, and community environment. In its implementation, to organize education, there is formal and non-formal education. Formal education such as schooling, students are nurtured and educated to become fully human beings, who can develop their potential to have physical and spiritual skills and health. As explained in the Law on the National Education System number 20 of 2003, namely:

Education is a planned awareness effort to produce an environment of teaching and learning processes so that students can actively develop their potential to have the power of self-control, personality, intelligence, spiritual spirituality, noble character, and the skills needed by themselves, society, nation, and country. $\langle\langle\langle\langle\rangle\rangle>\rangle$

The process of education must be carried out thoroughly, which leads to improvement and couples with the awareness of educators in educating the achievement of national education goals. As explained in the National Education Standards Agency (BSNP) Basic Education Content Standards (2006: 3), namely: National education based on Pancasila and the 1945 Constitution of the Republic of Indonesia functions to develop capabilities and shape the character and civilization of a dignified nation in the context of educating the life of the nation which aims to develop the potential of learners to become human beings who believe and have faith in God Almighty, have a noble, healthy physical and spiritually, knowledgeable, capable, creative, independent and become a democratic and responsible citizen.

Education becomes an essential thing in human life. Physical education is an inseparable part of education in making meaningful contributions to make changes in developing students' potential. Physical education can be defined as physical activity that aims to develop the potential of students so that they have skills in the cognitive, affective, and psychomotor domains as explained in the National Education Standards Agency (BSNP) Basic Education Content Standards $(2006,207)$ that physical education, sports, and health are an integral part of overall education aimed at developing aspects of physical fitness, movement skills, critical thinking skills, social skills, reasoning, emotional stability, moral actions, aspects of healthy lifestyle, and introduction of a clean environment through activities physical.

From the above explanation that physical education becomes an integral part of overall education, meaning that physical education is essential to be carried out, and without the implementation of physical education, the educational process will not be complete.

According to the Education Unit Level Curriculum in 2006, the fifth-grade standard competency of elementary schools that practices various variations of necessary motion into sports and games where there are rules modification of existing values and basic competence is the application of basic variations to modified small ball games (rounders). The researcher took the sample of fifth-grade students because the baseball game, according to KTSP, can be given to the 
fitness of class V children at Pelaihar State Primary School in the 2015-2016 academic year.

research conducted on baseball game material will occur.

Games of baseball and rounders are folk games that have been included in the curriculum. Baseball game rounders and rounders is one of the small ball games where there are elements of speed, accuracy, and agility.

All elements contained in baseball games rounders and rounders can improve muscle ability in a long time, for it can become a physical fitness support students who do baseball games. For class $\mathrm{V}$, children are outstanding to use to generate motivation to exercise in the field of sports games because sports games can be run without any time limit and can provide a sense of joy. However, in preliminary observations at SDN Pelabihari, it was found that the introduction of baseball game material was still lacking, so students did not know the advantages and disadvantages of baseball games. So the researcher gets clear pictures. The game of baseball, which is done continuously, can increase physical fitness. Many of us have encountered new forms of play, especially in areas that have large fields and many inhabitants, and even today, we still enjoy playing.

Playing is an activity that is carried out consciously, voluntarily without coercion, and not really in a time limit without binding rules. However, along with the uniqueness of playing is to make the seriousness of the players who are traversed with joy and tension in obtaining goals and not solely looking for material gain. The game is an activity carried out individually or in groups, children and adults, male and female, which makes people happy and happy to do it.

The real purpose of the game is in the game itself. What distinguishes the purpose of the game between one type of game to another is the actor who plays the game.

Physical education for teachers is desirable to be able to provide lessons such as techniques, fundamental movement skills, and game strategies, internalization of values (honesty, sportsmanship, cooperation), and familiarizing a healthy life.

Between physical fitness, there is a close relationship with health. Someone fit will attain a degree of good health. Therefore, the orientation of developing physical fitness in elementary school is fitness related or supporting health. According to Lutan (2001; 7), Physical fitness; (related to health) is the ability of someone to carry out physical tasks that require endurance, strength, and flexibility. A combination of exercise obtains fitness and one's ability itself (fitness related to performance; agility, balance, coordination, speed, power, and reaction time) components of physical fitness tied to health are muscle strength, flexibility, body composition, aerobic ability, and power hold muscles to improve health.

Physical Education is one part of sports education. This is in accordance with Law No. 3 of 2005 concerning the National Sports System (SKN), which explains that the scope of sport is divided into three parts, one of which is Sports Education.

However, researchers need to detect how much influence baseball game rounders and rounders have on increasing students' physical fitness. To that end, the researchers compiled a research plan to determine the effect of the baseball game and rounders on the addition of physical

\section{METHOD}

This research uses the method of Pre-experimental Designs (Nondesigns) with One-Group Pretest-Posttest Design. "In this design, there can be a pretest before being given treatment and a posttest after being given treatment. Thus the results of the treatment can be known to be more accurate because it can seek influence with the situation before being given treatment" (Sugiyono, 2014: 112).

The purpose of this research was to determine the effect of learning baseball game baseball and the effect of learning game rounders on the addition of physical fitness of students, and know how the learning process of sports baseball games can have a positive and significant effect when compared to the learning process of teaching and learning sports rounders on increasing physical fitness of students. The game of baseball and rounders in this research as a treat to give an idea of the influence of the sport.

\section{RESULTS AND DISCUSSION}

\section{A. Castle Ball Game}

The baseball game is included in the type of small ball sports, which requires an element of muscle strength to hit and throw, speed to run, agility to avoid throwing, flexibility to move, strength to play and balance, and skills including throwing, catching and hitting the ball. Therefore, the game of baseball also requires basic movements such as that according to Rusli Lutan (2001: 40) "Motion categories include: locomotor motion, manipulation motion, and stability motion (non-locomotor)" while locomotor motion such as running, road, manipulative movements such as hitting and throwing, for non-locomotor motion such as relaxation, flexibility. Besides, the game of baseball can affect the level of physical fitness of elementary school students because all activities of baseball games have a connection with the physical fitness component. Like the opinion (Rusli Lutan, 2001: 8) Fitness component of the health-related services: Muscle strength, muscular endurance, aerobic resistance and flexibility related to performance: coordination, agility, speed of movement, power, balance and reaction time.

The game of baseball can be given to the physical activities of school children because it can contribute to the improvement in the planned physical fitness of students. Habits of children who exercise regularly will have a level of physical fitness better when compared to children who are not accustomed to exercise. Children who often do physical fitness exercises (sports) will avoid physical weakness and fatigue. Furthermore, the results of this research indicate that there is a significant effect of game baseball to increase physical fitness in fifth-grade students of Pelaihari Pelaihari Elementary School for the 2015/2016 Academic Year, this becomes important information for physical and health physical education teachers (PJOK) in general in improving physical fitness.

Based on the research results obtained for the ball game Kasti shows that $\mathrm{t}$ arithmetic, -8.21 smaller than $\mathrm{t}$ table, 1.68 indicates that there is a significant difference between the average values for the pre-test data is 2.96 and the average value the average for the post-test data was 4.22. These results indicate the physical fitness level of the fifth-grade 
students of the State Elementary School after receiving learning by playing ball Castles increased by 1.26 or 42 , $57 \%$.

\section{B. Rounders Game}

Rounders game is also included in the type of small ball sports which is a physical activity that is not different from baseball games that require good physical freshness because this game also requires an element of muscular strength to hit and throw, speed to run, agility to avoid the tick of the ball, flexibility to dodge, resistance and balance and skills include: throwing, catching and hitting the ball. (Subarjah, 2005: 7.15) Rounders play is a physical activity that requires functional physical fitness because rounders are done by throwing fast shots and strong punches right against the ball and running as fast as possible.

Rounders require strength, speed, agility, flexibility, strength and balance, and skills. Where skills include: throwing, catching and hitting balls. Therefore rounder games can also affect the level of physical fitness of elementary school students because all-rounders game activities are related to the physical fitness component. Like the opinion (Lutan, 2001: 8) Fitness component of the health-related services: Muscle strength, muscular endurance, aerobic resistance and flexibility related to performance: coordination, agility, speed of movement, power, balance and reaction time

Teaching and Learning of rounders can also be given to help in the planned physical fitness of students. Habits of children who exercise regularly will have a level of physical fitness better when compared to children who are not accustomed to exercise. The results of this research indicate there is an influence of the rounders game on increasing physical fitness in fifth-grade students of Pelaihari SubElementary School in the 2015/2016 academic year.

Based on the research results obtained for the Rounders game shows that $\mathrm{t}$ count -8.61 smaller than $\mathrm{t}$ table, 1.68 this indicates that there is a significant difference between the mean values for the pre-test data is 2.96 and the average value the average for the post-test data was 4.13. These results indicate the level of physical fitness of grade $\mathrm{V}$ students of SDN Pabahanan after getting learning with Rounders ball games increased by 1.17 or by $39.53 \%$.

\section{Game of Baseball and Rounders}

Based on the results of this research using the QuasiExperimental method and the Nonequivalent-Group Design obtained from baseball games and rounders have shown that the $\mathrm{t}-17.947$ count is smaller than the $\mathrm{t}$ table, 1.68 this indicates that there is a significant difference between the mean values the average for the pre-test data was 2.96 and the average value for the post-test data was 4.17. These results indicate the physical fitness level of the fifth-grade students of SDN Pabahanan after getting learning with the ball game Castles, and rounders increased by 1.21 or by $40.87 \%$.

In this case, it can be said that the increase given by the learning of the ball game of Castles and Rounders to the level of physical fitness of fifth-grade students of SD Negeri Paabahan, Pelaihari District, Tanah Laut Regency 2015/2016 Academic Year by $40.87 \%$. so this is a significant improvement before and after receiving learning through baseball games and rounders for 16 meetings
The results of this research indicate there is an effect of learning baseball games and rounders on increasing physical fitness in fifth-grade students of Pelaihari Pabahan Elementary School in the research, before and after being given treatment. Because the known probabilities $(\mathrm{T}$-stat $)=$ $-17,947<0.05$. This is due to the continuous training for eight weeks / 16 meetings.

Because T arithmetic located in the Ho area is rejected, it can be concluded that the TKJI before being given treatment and after being given treatment is not the same or significantly different, which means that the tests carried out were significantly successful.

Limitations of the research, namely in the Pabahan soccer field, Pelaihari subdistrict, Tanah Laut Regency, so that if the research was carried out in other places, the results might be different. However, this place can represent the children to be a place of research, and even if the results of research in other places will be different from the results of research conducted by the author. The time limitation of this research was carried out during the making of the thesis, which is for eight weeks, therefore in this research, assisted by several colleagues in the implementation of the test to facilitate the implementation, using TKJI measurement tests.

From the limitations above are the shortcomings of the research and at least can be used as a temporary conclusion because this can be tested again in another place and with other results as well. So for the hypothesis that the authors propose that TKJI given to children in grade V SDN Paberdekaan Subdistrict Pelaihari, Tanah Laut Regency, can give effect after being given treatment.

Thus it can be concluded that there is an effect of learning baseball game (X1) and Rounders (X2) on increasing physical fitness of the fifth-grade students at Pelaihari Pelaihari Elementary School. Ad'dien, H. (2011). Mentioning that baseball games can improve fitness in children, according to Riyanto, P. (2013) said that the game of baseball can improve one's fitness, while Waldi, W., Simanjuntak, V., \& Yunitaningrum, W. ( 2010) said that the little ball game made by the game would make you happy and in shape. From some of the theories above that learning, games will get fun and fitness for children.

\section{CONCLUSION}

Based on the results of the analysis and discussion of the research, it can be concluded that: 1) There is an influence of learning the game of Castles to increase the physical fitness of the students significantly. It means the exercises that had been conducted continuously for eight weeks have a positive impact on students' physical fitness.. 2) There is an effect of the learning of the Rounders game on increasing the physical fitness of students. It implies that the game of castles and rounders can be implemented to improve the physical fitness of students, especially for the fifths grade students (about 12 years old)

\section{ACKNOWLEDGMENT}

We want to be grateful to the Dean of Teacher Training and Education Faculty, Lambung Mangkurat University, who has supported us in the form of funding. Therefore we could join this International Conference. 


\section{REFERENCES}

[1] Badan Standar Nasional Pendidikan (BNSP), 2006. Standar Isi Pendidikan Dasar dan Menegah. Jakarta, BSNP

[2] Herman Subarjah, 2005 Permainan Kecil disekolah Dasar, Jakarta Universitas Terbuka

[3] Rusli Lutan, 2001 Azas-Azas Pendidkan Jasmani, Jakarta, DepDiknas

[4] Rusli Lutan, 2001 Mengajar Pendidkan Jasmani, Jakarta, DepDiknas

[5] Rusli Lutan, 2001 Pendidikan Kebugaran Jasmani, Jakarta, DepDiknas

[6] Sugiyono,.2014. Medtode Penilitian Kombinasi. Bandung. Alfabet

[7] Ad'dien, H. (2011). Perbandingan Pengaruh Latihan Antara Permainan Kasti Dengan Permainan Benteng Terhadap Peningkatan
Kesegaran Jasmani Dan Vital Kapasitas Paru-Paru Murid Sd Kecamatan Bacukiki Kota Pare-Pare. COMPETITOR: Jurnal Pendidikan Kepelatihan Olahraga, 3(2).

[8] Riyanto, P. (2013) Pengaruh Permainan Bola Kasti terhadap Peningkatan Kemampuan Gerak Umum (General Motor Ability). Journal Sport Area, 2(1), 53-63.

[9] Waldi, W., Simanjuntak, V., \& Yunitaningrum, W. (2010) Pengaruh Modifikasi Pembelajaran Bola Kecil terhadap Kebugaran Jasmani pada Siswa Sdlb-c Tunagrahita. Jurnal Pendidikan dan Pembelajaran Untan, 4(6). 